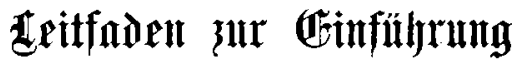

\author{
in bas
}

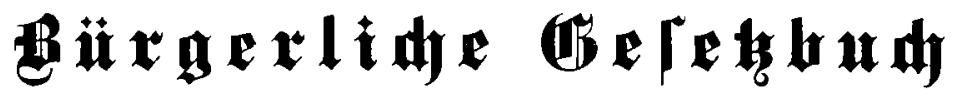 \\ Ino}

Frine Atrhengrerte

iitr

(5eridhts

\section{Dr. F. Fioler,}

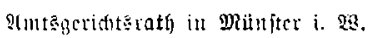

\author{
Betlin SW.
}

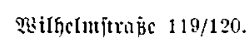

3. (Gutteutag, Berfagsbudhaubfung. 1898. 


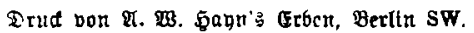

